\title{
Kernos
}

Revue internationale et pluridisciplinaire de religion grecque antique

$24 \mid 2011$

Varia

\section{The Sanctuary of Zeus Ammon at Kallithea (Chalicidice)}

\section{Elisavet Bettina Tsigarida}

\section{OpenEdition}

\section{Journals}

Electronic version

URL: http://journals.openedition.org/kernos/1964

DOI: 10.4000/kernos. 1964

ISSN: 2034-7871

\section{Publisher}

Centre international d'étude de la religion grecque antique

\section{Printed version}

Date of publication: 1 January 2011

Number of pages: 165-181

ISSN: 0776-3824

\section{Electronic reference}

Elisavet Bettina Tsigarida, «The Sanctuary of Zeus Ammon at Kallithea (Chalicidice) », Kernos [Online], 24 | 2011, Online since 01 February 2014, connection on 02 May 2019. URL : http:// journals.openedition.org/kernos/1964; DOI : 10.4000/kernos.1964 
Kernos 24 (2011), p. 165-181.

\title{
The Sanctuary of Zeus Ammon at Kallithea (Chalicidice)
}

\begin{abstract}
This paper presents the sanctuary of Zeus Ammon at Kallithea, Chalcidice, where three related deities were worshipped. The cult of Dionysos and probably that of the Nymphs began in the late 8th century BC or earlier in a cave in the southern part of the sanctuary. The cult of Zeus Ammon was introduced in the first half of the 4th century BC, and in the second half of the century a Doric peristyle temple and an open-air corridor running parallel to the temple and flanked by two rows of monumental bases that supported sculpture were built. The cult of Asclepios was introduced in the same period. In the 2 nd century $\mathrm{AD}$ the sanctuary reached its apogee: the area was reorganized, the old buildings were altered and new edifices (two oblong buildings for spectators in front of the temple of Zeus Ammon, a balneum-therapeuterion etc.) were built.

Résumé : Cet article présente le sanctuaire de Zeus Ammon à Kallithea en Chalcidique, où trois divinités liées entre elles étaient honorées. Le culte de Dionysos et, probablement, celui des Nymphes a commencé à la fin du VIII siècle av. J.-C., ou plus tôt, dans une grotte située dans la partie sud du sanctuaire. Le culte de Zeus Ammon a été introduit dans le premier quart du IV siècle av. J.-C. et, dans la deuxième moitié du siècle, on a construit le temple dorique péristyle et un portique ouvert parallèle au temple et flanqué de deux rangées de bases monumentales qui soutenaient des sculptures. Le culte d'Asclépios a été introduit à la même période. Au $\mathrm{II}^{\mathrm{e}}$ siècle de notre ère, le sanctuaire atteint son apogée : l'espace est réorganisé, les anciens bâtiments sont transformés et de nouveaux édifices sont construits (deux bâtiments allongés pour les spectateurs en face du temple de Zeus Ammon, un lieu thermal et de cure, etc.).
\end{abstract}

The sanctuary of Zeus Ammon at Kallithea, Chalcidice is situated by the sea, in a beautiful, forested area of the western peninsula of the Chalcidice. The site was discovered in 1968, when illegal building activities destroyed part of the foundation and the crepidoma of a monumental building, which afterwards proved to be a temple. The rescue excavation that followed from 1969 to 1970 brought to light a temple which was attributed to Zeus Ammon, following the discovery of a votive inscription to the god. ${ }^{1}$ South of the temple, research revealed the remains of a shrine which was attributed to Dionysos on the basis

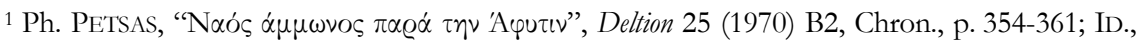

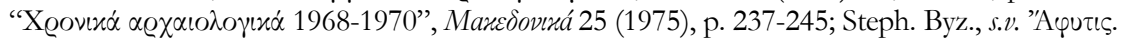


of the name of the god inscribed on many sherds found there. This shrine was recorded in ancient Greek literature. ${ }^{2}$

The sanctuary was excavated again from 2005 to 2008, as part of the project "Sanctuary of Zeus Ammon of Chalcidice - enhancement and presentation to the public", financed by the European Union and the Greek State. This recent excavation was carried out in three areas: a) the shrine of Dionysus and the Nymphs, b) the temple of Zeus Ammon, and c) a Roman bath discovered north of the temple. ${ }^{3}$

This paper aims at the presentation, dating and interpretation of the monuments which came to light in the sanctuary as well as the discussion of the identification of deities worshipped there and their cult practices.

\section{The history of the area}

The sanctuary extends from the slope of a forested hill with water springs and waterfalls down to the sea; originally, this area was in the territory of the Eretrian colony of Aphytis. ${ }^{4}$ Later, after the founding of Cassandreia in 315 BC, it was incorporated into its territory and became the most important sanctuary of the city and the whole peninsula until late antiquity.

From the Byzantine era onwards the area constituted the territory of the Metochi of the Russian monastery of Panteleemon on Mt. Athos and was equipped with water-mills and a port for the exportation of the agricultural products of the entire peninsula of Cassandra. ${ }^{5}$ The masonry of the ancient buildings was used for the construction of the Metochi (buildings used by the monks), while it is reported by travelers that the monks and local population were often engaged in illegal digging. Statues, inscriptions, antefixes, fragments

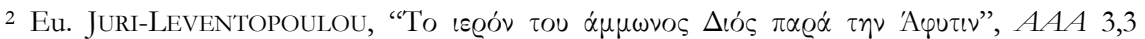

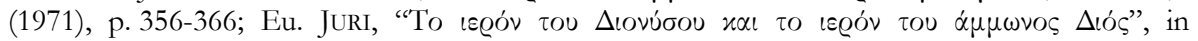
U. JANTZEN (ed.), Neue Forschungen in griechischen Heiligtümern. Symposion in Olympia, 10-12 Oktober 1974, Tübingen, 1976, p. 134-150; Xen., Hellenica V, 3, 13-19.

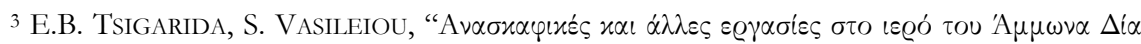

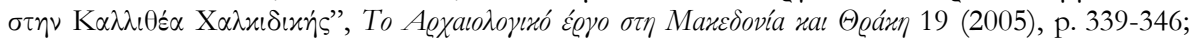

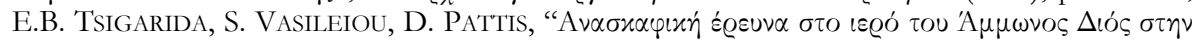

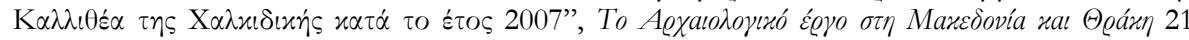
(2007) in press.

${ }^{4}$ Xenophon calls it "the sanctuary of Dionysos at Aphytis" (Xen., Hellenica V, 3, 19). See also M. ZAhrnt, Olynth und die Chalkidier, Munich, 1971, p. 164-169; F. PAPAZOGLOU, Les villes de Macédoine à l'époque romaine, BCH Suppl. XVI (1988), p. 427-428; E. VouTIRAs, "To เe@ó tov

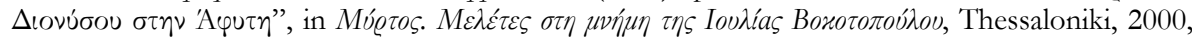
p. 631-640.

${ }^{5}$ D. Feisel, M. SÈve, "La Chalcidique vue par Ch. Avezou”, BCH 103 (1979), p. 260; Zahrnt, o.c. (n. 4); PApazoglou, o.c. (n. 4); Voutiras, l.c. (n. 4). 
of simas, pottery and other objects were taken to the Monastery, where they are still housed. ${ }^{6}$

\section{The sanctuary of Dionysos ${ }^{7}$}

The few remains of the cult of Dionysos were found near a cave, which is located at the foot of a forested slope in the southern part of the sanctuary, in an area with dense vegetation, rocks and waterfalls. ${ }^{8}$ The excavation of the area yielded Bronze Age pottery, indicating the area has been inhabited since the Bronze Age; however, on the basis of pottery, the cult of Dionysos dates to the second half of the $8^{\text {th }}$ century BC or earlier. ${ }^{\text {? }}$

No temple of the god has been discovered in that area and the only structures of the shrine are a monumental staircase and the remains of a fountain house. It is assumed that Dionysos and the nymphs were worshipped in the cave which was a common ritual practice in ancient Greece (Fig. 1). However, no cult evidence has been found inside the cave. ${ }^{10}$ Only a few sherds, inscribed with the name of the god, were discovered in front of its entrance (Fig. 2).

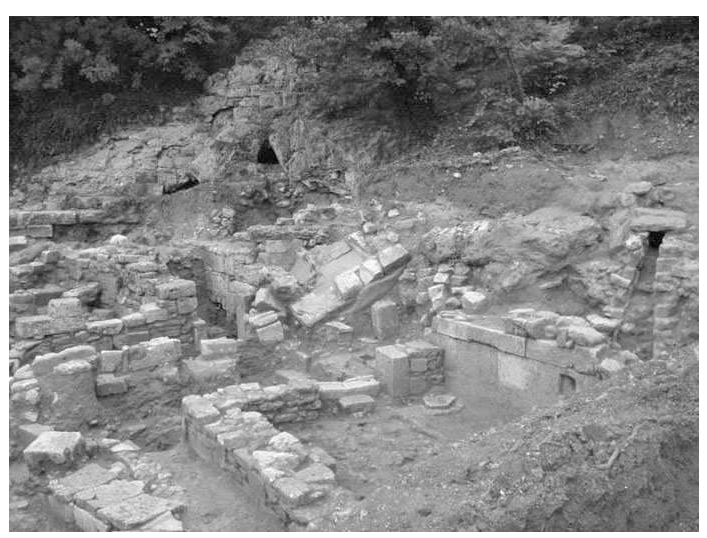

Fig. 1: The cave in the southern part of the sanctuary and the surrounding area, the fountain house and the fallen Roman cistern. This lack of evidence is probably due to intense building activities in the whole shrine of Dionysos in the Roman Imperial Period and afterwards. For the same

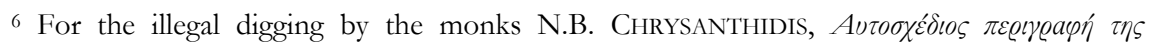

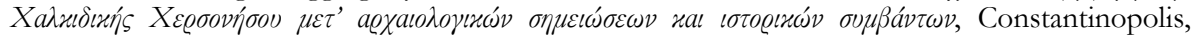

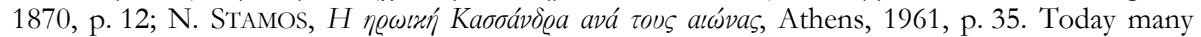
antiquities are housed in the Library of the Monastery, S. ATHANASIADis, Ch. CHEILAS, 'A jiov

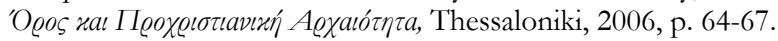

7 The sanctuary of Dionysos is recorded by Xenophon (see n. 2). See also VOUTIRAS, l.c. (n. 4).

8 The area is much changed today: the waterfalls have disappeared and the water from a spring in the area is piped to a nearby hotel. Eu. Poulaki-Pantermali, M. VAxevanopoulos,

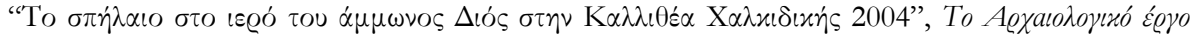

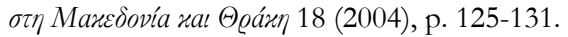

${ }^{9}$ See Voutiras, l.c. (n. 4). The pottery implies that it started earlier in the $10^{\text {th }}$ or $9^{\text {th }}$ cent. BC.

10 The cult of the Nymphs has been suggested by Eugenia Juri, see JuRI-LEVENTOPOULOU, l.c. (n. 2). For discussion of the cult of Dionysus in caves, see VOUTIRAS, l.c. (n. 4), p. 635 and 638-639 with bibliography. The cult is also related to Dionysus Zagraios, son of Zeus and Persephone. 
reason, it cannot be certain whether the pots inscribed with the name of the god found in front of the cave were originally used there or had fallen from above. The main constructions of the sanctuary of Dionysos that came to light were a staircase, parts of a fountain house, and cisterns.

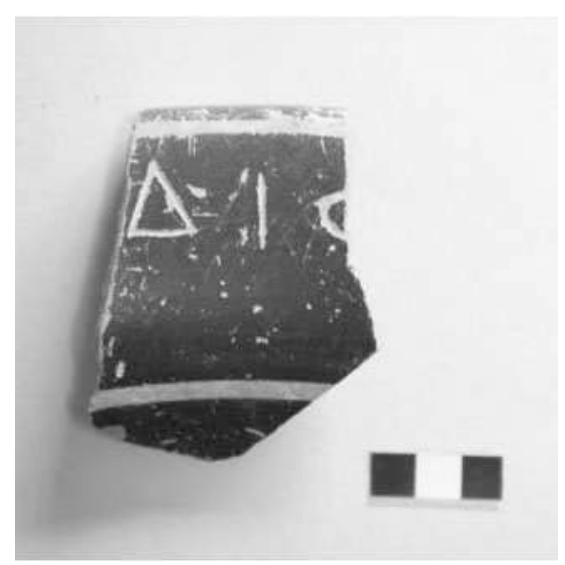

Fig. 2

The recent excavation focused on the investigation of the monumental staircase that constituted the southern border of the sanctuary of Dionysos and led to the cave and above (Fig. 3). The staircase was necessary because of the irregular and damp terrain. It is highly probable that the sanctuary was organized into terraces and the staircase provided access to them. It is $1.60 \mathrm{~m}$. wide and was partially cut into the rock and partially built of stone masonry. The recent investigation revealed that its two ends are not preserved: the eastern lower part of the staircase had been destroyed by illegal digging in the late 60 s and the western upper part was destroyed due to the weathering of the rock and constant use of the area. Therefore, it is not clear where it led, or what function it had, i.e. whether it served ritual needs in processions or just practical needs.

The major part of the staircase was founded in layers that have been disturbed. Only a small part of its foundation lay on an undisturbed layer containing $4^{\text {th }}$ century pottery and because of the uniformity in construction, it is assumed that the whole staircase was built in the $4^{\text {th }}$ century BC.

The area north of the staircase was covered with debris. Part of a fountain house of the first half of the $4^{\text {th }}$

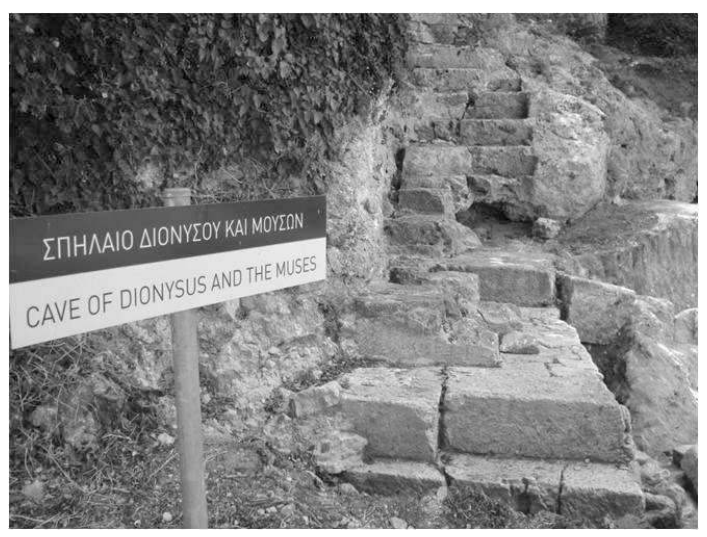

Fig. 3 : The staircase of the sanctuary of Dionysos. century was discovered under it during the recent excavation. It consists of a wall, which also served as a retaining wall, and a pavement oriented N-S. Originally, the wall must have been equipped with holes from which water gushed. The fountain house was destroyed during Cassander's or more probably, Antigonos Gonatas' reign and part of it was repaired in the Roman 
Imperial period. Only the northern section of the wall is preserved to a height of $2 \mathrm{~m}$., while part of the southern section was found under a Roman floor and a fallen Roman cistern. In the preserved part there is a hole that most probably received a bronze lion head through which water spouted to fill basins or pots set on the pavement below. Water reached the fountain house through an underground built pipe-gallery, $1.8 \mathrm{~m}$. high, which formed the continuation of the cave. ${ }^{11}$ The pipe ends behind the wall of the fountain house and is connected to it, suggesting that they were built together (Fig. 4). A second spout probably existed in the destroyed southern part of the wall, where a fragment of a marble basin was found.

A cistern made of bricks and covered with hydraulic plaster was discovered immediately below the cave entrance, on top of the destroyed wall of the fountain house (Fig. 1). It dates to the Roman Imperial period, when only the northern part of the fountain house was in use. It would appear that the area of the cave with the water was reorganized with large cisterns in Roman Imperial times.

Water from the area was

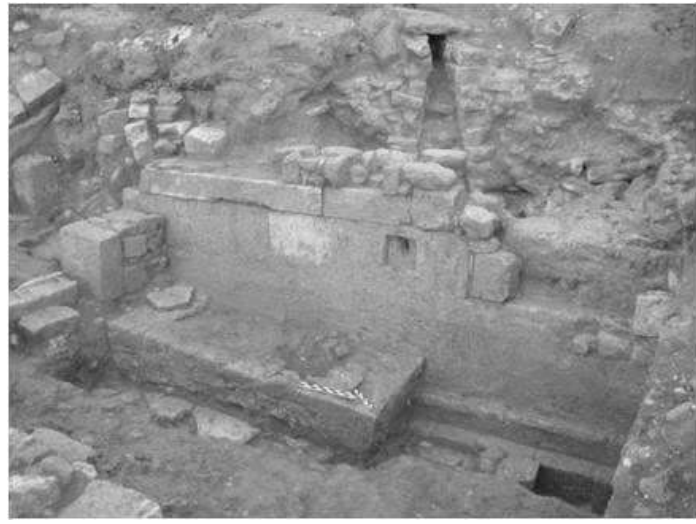

Fig. 4: The preserved part of the fountain house: water reached the fountain house through the underground built pipe on top of the spout. used after the destruction and abandonment of the sanctuary in the $4^{\text {th }}$ century AD. Under the heavy deposits of lime formed by the presence of water, which had covered a great part of the area north of the staircase, a water-mill of the overshot type was discovered. ${ }^{12}$ Its water wheel, in an oblong hole within the rock, was rotated by waterfalls (Fig. 5). Its vertical and horizontal drums along with the millstones were accommodated within a small room found next to the wheel. This type of mill was known to

11 According to the geological research that has been carried out in the cave and surrounding area, the cave terminated in an underground built pipe-gallery, through which water was conveyed to the fountain house, Poulaki-Pantermali, Vaxevanopoulos, l.c. (n. 8); Gr.

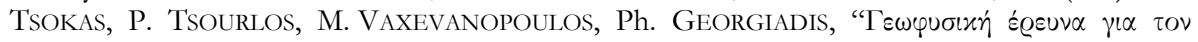

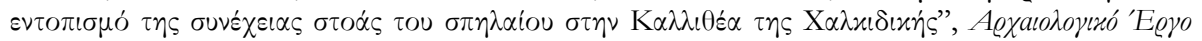

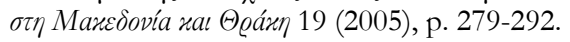

12 Vitruvius, X, 5, 2 and K.D. White, Greek and Roman Technology, London, 1984, p. 65-67. A similar water-mill was discovered in the Athenian Agora: A.W. PARSONS, "A Roman Water-Mill in the Athenian Agora. A new view of the evidence", Hesperia 51 (1936), p. 70-90 and R.J. SpaIN, "The Roman Watermill in the Athenian Agora. A New View of the Evidence", Hesperia 56 (1987), p.335-53. 
Vitruvius, but it was very rare before the medieval period. Various millstones, originally used in the water mill, were discovered dispersed in the area. The water mill was constructed in the late $4^{\text {th }}$ or early $5^{\text {th }}$ century $\mathrm{AD}$ with an auxiliary room, which used the preserved wall of the fountain house.

\section{The sanctuary of Zeus Ammon}

\subsection{The temple}

The temple was discovered and excavated in the late $60 \mathrm{~s} .{ }^{13}$ Originally, it was a peristyle temple with 6 columns on its narrow and 11 on its long side. It consisted of a pronaos and a cella. Its dimensions $(10.51 \times$ $21.43 \mathrm{~m}$.) recall those of the temple of Asclepios at Epidaurus (Fig. 6). Today only six rows of ashlar masonry the foundation, euthenteria and crepidoma - and a small part of the stylobate are

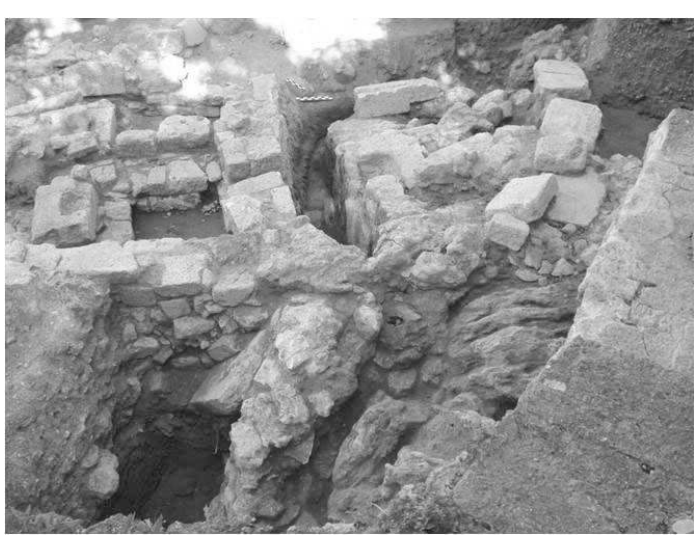
preserved, while a few Doric

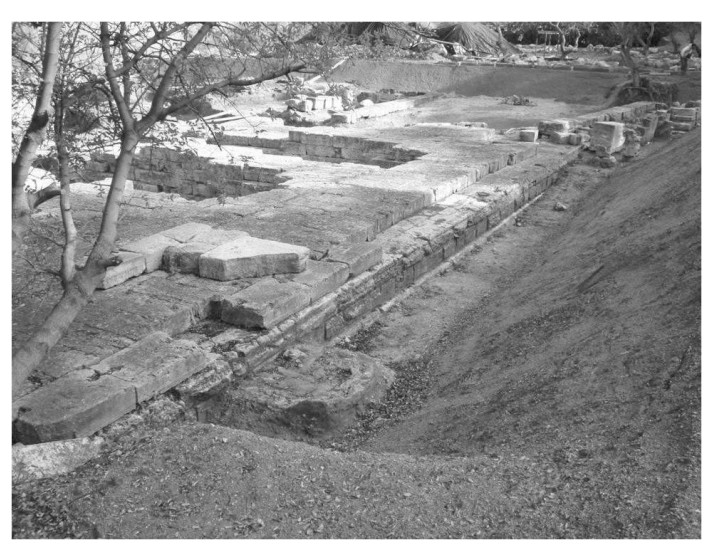

Fig. 5 : The water mill.

column shafts and capitals are the only remains of the pteron (Fig. 7).

The dating of the temple is based on resemblances of architectural details and not on stratified data. The temple's excavators dated it to the second half of the $4^{\text {th }}$ century $\mathrm{BC}$, on the basis of the resemblance of its capitals to those of the temple of Athena

Fig. 6 : The temple of Zeus Ammon. Alea at Tegea, the proportions

13 A rescue excavation followed the destruction of the foundation and the crepidoma of the temple by three parallel illegal trenches, which are still visible today. The temple was attributed to Zeus Ammon after the discovery of a fragment of a lekane with the name of the god inscribed on it, during the rescue excavation, see VouTIRAs, l.c. (n. 4), p. 360. For the excavation see PETSAS, l.c. (n. 1). 
of its stone entablature, and its tiles, which are similar to those of the South Stoa at Corinth. ${ }^{14}$ The excavation of the 1960 s yielded a variety of antefixes and simas with painted and relief decoration and it was assumed that they all came from the temple (Fig. 8-11). However, the discovery of similar finds in the whole excavated area of the sanctuary during recent investigation would suggest that their attribution needs to be reconsidered.

The temple was destroyed towards the end of the $4^{\text {th }}$ century, probably by the earthquake which also destroyed Aphytis, or later, during the invasion of the Gauls. ${ }^{15}$ It was immediately repaired; the entablature was replaced by a marble one and the original tiles of the roof by Hellenistic Corinthian of brown clay. ${ }^{16}$ According to the data of the excavation of the 60s, another repair took place in the Roman Imperial period,

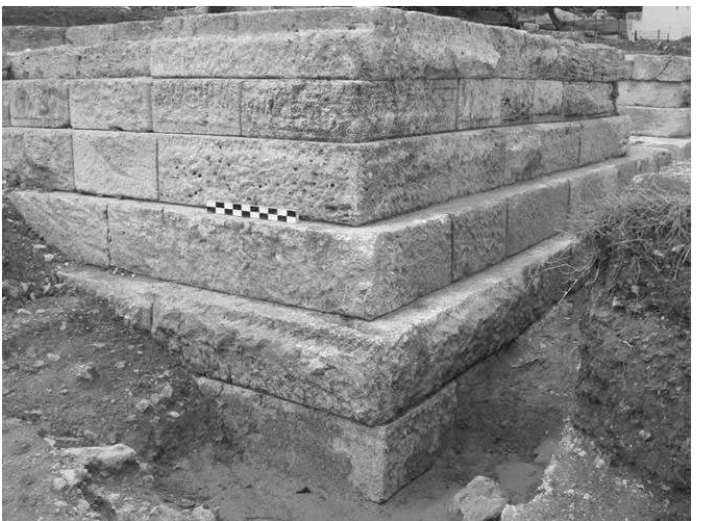

Fig. 7 : Foundation - euthenteria - crepidoma stylobate of the temple of Zeus Ammon.

probably in the $2^{\text {nd }}$ century AD. The tiles were again replaced by Laconian and the exterior underwent major changes. Two oblong parallel buildings were built in front of the temple to accommodate the spectators who watched the rituals that took place there. ${ }^{17}$ Doric and Ionic architectural members are incorporated into the walls of these buildings, suggesting that various Classical or early Hellenistic edifices in the sanctuary had already been destroyed when they were built (Fig. 12). The incorporation of Doric stone capitals from the temple implies that the pteron probably no longer existed in this period, which means there were major alterations to the temple's plan.

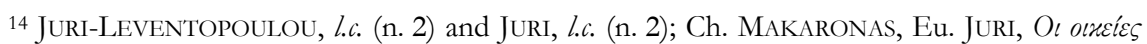

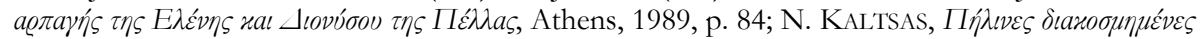

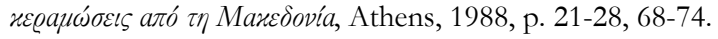

15 The excavators of the temple suggested a destruction by the Gauls, see JURI and JURILeVentopoulou, l.c. (n. 2). The recent excavation of the ancient city of Aphytis has shown that the city was not destroyed by the Macedonian king Philip II, but was destroyed suddenly by

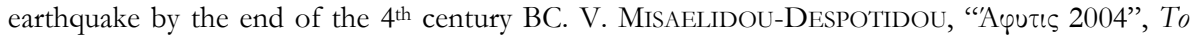

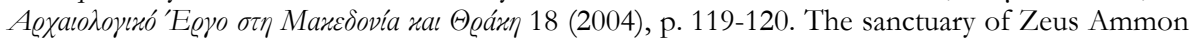
is found near Athytos (Aphytis) and was probably destroyed by the earthquake as well.

${ }^{16}$ Juri, l.c. (n. 2), p. 149-150 and JuRI-LEVENTOPOUlOU, l.c. (n. 2), p. 358-361.

17 See supra, n. 16. 
Furthermore, a small altar (Fig. 13) of the Roman period was also found between the two parallel buildings, on top of an earlier wall, ${ }^{18}$ and a basin dexamene - dating to the $3^{\text {rd }}$ century $\mathrm{AD}$ was built at the northern part of the western wall. ${ }^{19}$

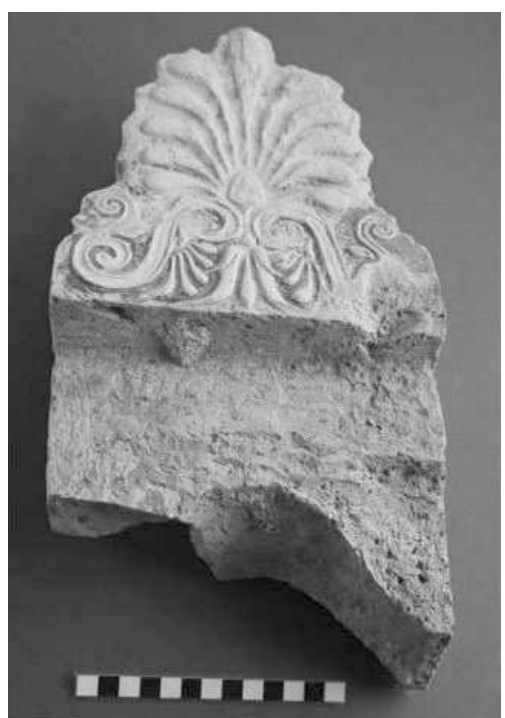

Fig. 8: Palmette antefix from the excavation of the temple of Zeus Ammon.

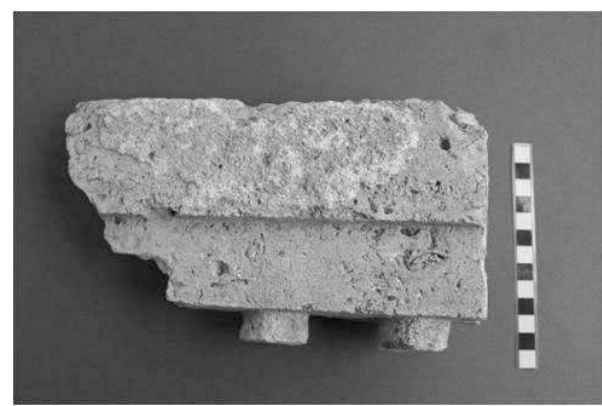

Fig. 10: Part of the original entablature of the temple from the excavation of the temple of Zeus.

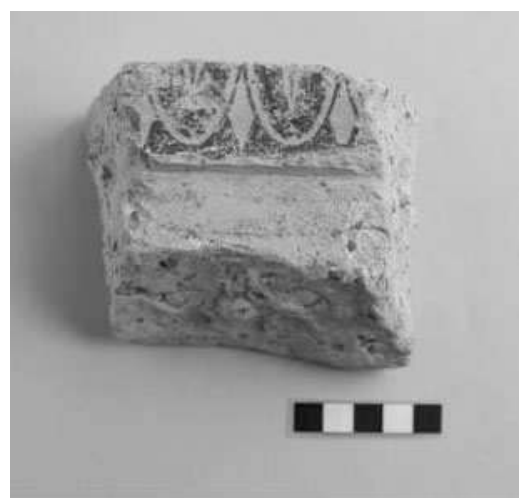

Fig. 9: Terracotta sima from the excavation of the temple of Zeus Ammon.

Fig. 11: Cover tile of the original roof of the temple of Zeus Ammon.

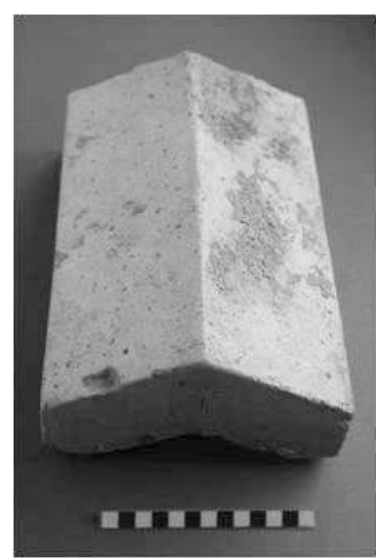

18 See supra, n. 16.

${ }^{19}$ Its dimensions are $1.21 \mathrm{~m} \times 1 \mathrm{~m} \times 50 \mathrm{~m}$. It recalls the dexamene of Zeus Hypsistos at Dion,

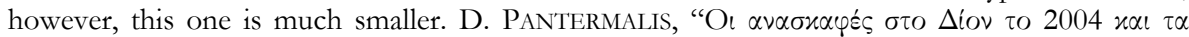

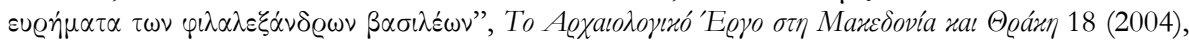
p. 377-382. 
The recent investigation yielded a great number of finds including pottery, architectural members, fragments of marble statues and smaller finds, most of which are unstratified, since they were found in the trenches of the earlier excavation.

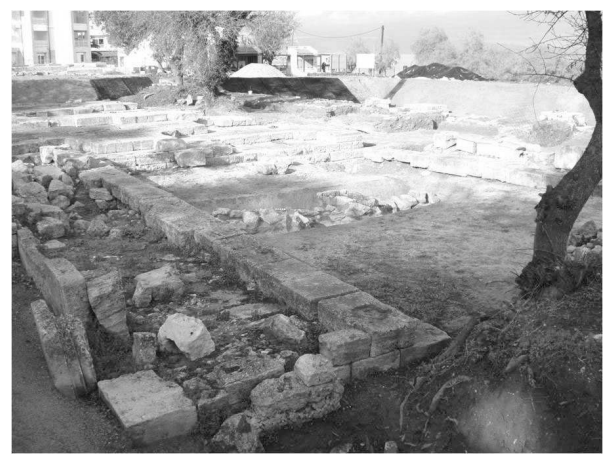

Fig. 12: One of the two parallel Roman buildings that accommodated the spectators in front of the temple of Zeus Ammon.

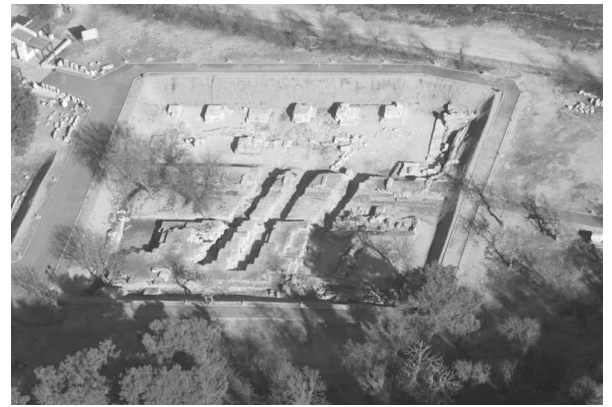

Fig. 14: Aerial photograph of the temple and open air corridor flanked by the two rows of monumental basis.

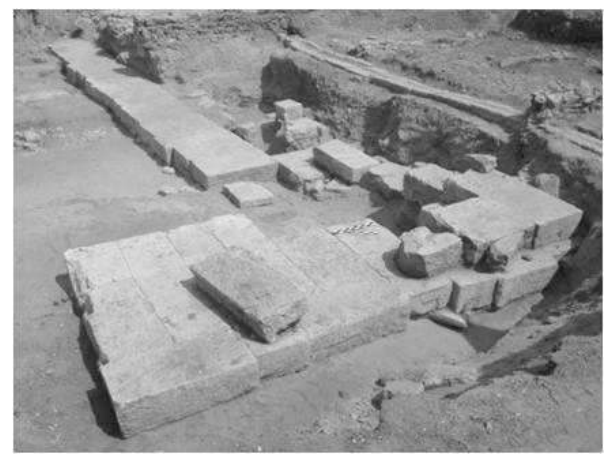

Fig. 16: The lowest course of stones of the high bases and other masonry blocks set on the rubble and stone floor.

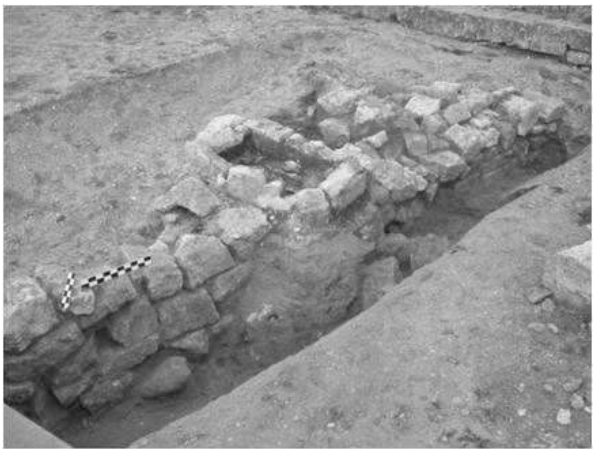

Fig. 13: The Roman altar in front of the temple of Zeus Ammon.

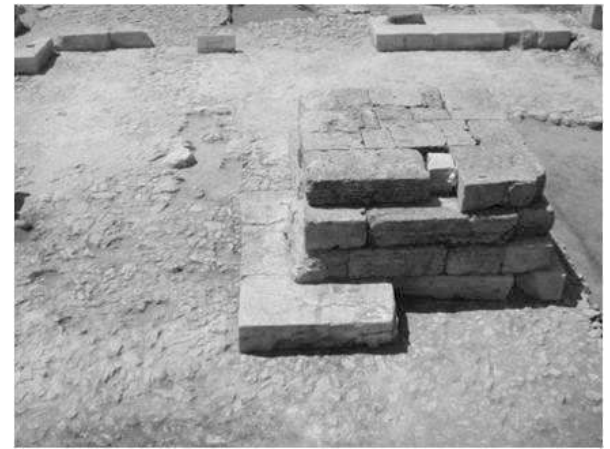

Fig. 15: A high base with its foundation on the floor of rubble and stone.

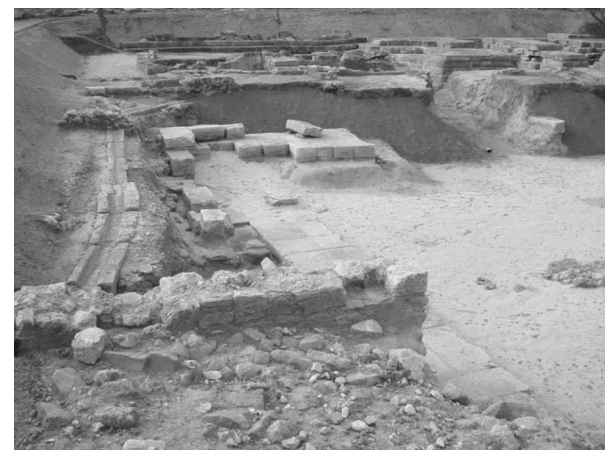

Fig. 17: The wall with gamma-shaped ends south of the bases. 


\subsection{The monumental bases east of the temple}

The recent excavation of the area east of the temple brought to light two parallel rows of monumental bases, oriented N-S. ${ }^{20}$ The eastern row consists of six bases, while the western of two and an oblong construction, like an exedra (Fig. 14). The bases are almost square in plan with each side measuring approximately 3 meters. Their height differs - three are higher than the others - and their foundations lie at different layers and levels. The three high monumental bases and part of the construction - exedra - were set on a floor of stones and rubble. The very small number of finds from the floor included pottery, a coin of Vottike of the first half of the $4^{\text {th }}$ century BC, and a coin of Amyntas II (Fig. 15).

The other monumental bases were set higher than those noted in the previous paragraph, in a layer of sand that covered the floor. All the bases were built together. The resemblance of their material and construction to those of the temple suggests that they belonged to the same building project.

The bases were constructed from reused materials. The masonry blocks of the lowest course of the three high bases and the southern part of the exedra, which were set on the rubble and stone floor, differ from the upper courses of masonry and protrude from the monumental bases, suggesting that they did not originally belong to them; their lower part was earlier and belonged to a building whose foundation lay on the stone and rubble floor that no longer exists. Some other dispersed masonry blocks, which were originally set on the floor, seem to have belonged to this earlier construction which dates to the first half of the $4^{\text {th }}$ century, according to the finds from the floor (Fig. 16). The foundation of a wall with gamma-shaped ends, which was found south of the bases and dates to the same period, is also related to this early building (Fig. 17).

Later, after the destruction of this construction, it was decided to use certain parts of its foundation for the monumental bases' lowest course. When the monumental bases were in use, the original floor had already been covered by earth; thus, the lowest course of the three high bases was not visible.

There are also other constructions in the area predating the temple. The wall below the Roman altar in front of the temple (Fig. 13) and parts of similar walls under the Roman oblong buildings between the temple and the monumental bases imply that they probably belonged to a building of an earlier phase. ${ }^{21}$

20 Tsigarida, Vasileiou, Pattis, l.c. (n. 3).

21 The wall below the Roman altar in front of the entrance of the temple of Zeus Ammon was excavated by $\mathrm{Ph}$. Petsas and Eu. Juri and was interpreted as the original altar of the sanctuary. However, the recent investigation did not reveal any trace of fire or other evidence of an altar. Therefore, it has been suggested that the wall below the Roman altar and other walls discovered below the Roman buildings which are found east of the temple, between the temple and the monumental bases, belong to buildings that predated the temple and which were 
This new evidence implies that the Temenid Macedonians built the temple and the monumental bases in the second half of the $4^{\text {th }}$ century $\mathrm{BC}$, in an area of the sanctuary where buildings already existed. The identity of the king who ordered the construction of the new temple and the monumental bases is not known, because, as was noted above, the dating cannot be accurate. Three kings reigned in the second half of the $4^{\text {th }}$ century: Philip II, who had received an oracle to sacrifice to Zeus Ammon; Alexander the Great, who was considered to be the son of the god, ${ }^{22}$ and Cassander, who founded Cassandreia and reorganized the area. According to the finds, the two latter seem more probable.

The buildings of the first phase date to the first half of the $4^{\text {th }}$ century and they are related to the colony of Aphytis..$^{23}$ Plutarch has recorded that the Spartan king Lysander stopped besieging Aphytis and freed the city in 403 BC, when the god appeared to him by night and asked him to do so. Lysander ordered the inhabitants of Aphytis to sacrifice to Zeus Ammon. ${ }^{24}$ It is highly probable that the cult of the god was introduced to the sanctuary after this event. There is no evidence of destruction of the earlier buildings. Their construction was probably not finished when the Macedonians conquered the area and planned a different building project with a more monumental temple and an open-air corridor flanked by two rows of monumental bases. The material of the previous unfinished buildings was used for the new constructions.

\subsection{The cult of Zeus Ammon}

Water was essential in the cult of Zeus Ammon and the sanctuary area was appropriate, because of its waterfalls and springs. ${ }^{25}$ When the worship of the god was introduced and the first buildings were constructed, a water supply system was organized to bring water from the springs to the cult buildings of Zeus Ammon. The fountain house near the cave of Dionysus was built in that period and water was piped into the area of the cult of the god. Later, after the building of the temple, the fountain house was in use and a clay pipe carried water to a stone construction in front of the temple. A water channel took the water from this construction to the sea or more probably a nearby cistern (Fig. 18). Only one masonry block from this construction is preserved and its original form remains unknown. The pipe and the water channel, which came

probably contemporary with the buildings discovered in the area of the monumental bases. See also Tsigarida, Vasileiou, Pattis, l.c. (n. 3).

22 Plutarch, Alexander, 14.

23 The existence of an oracle of Zeus Ammon at Aphytis is recorded in Steph. Byz., s.v.

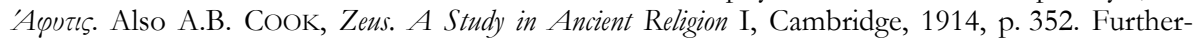
more, the cult of the god is also suggested by his head on the coinage of the city and subsequently that of Cassandreia.

24 Plut., Lysander, 299a-c and Pausanias, III, 18, 3.

25 Pliny, Nat. Hist. II, 228. CoOK, o.c. (n. 23), p. 368-369; Diodorus, XVII, 50. 
to light during the recent excavation, were constructed at the same time as the temple and were used throughout the Hellenistic period, until the sanctuary was reorganized in the Roman Imperial Age.

The cult of Ammon started from Siwah. Zeus, through contact with Ammon, became the horned Zeus Ammon at Cyrene. ${ }^{26}$ His cult was adopted by the Dorians after the founding of the colony of Cyrene and temples of Zeus Ammon were built in Thebes, Sparta, Gytheion, Piraeus etc. The god was accorded official libations at Olympia as well and was worshipped in a triad of Zeus Ammon, Hera Ammonia and Parammon.

Due to the Egyptian origin of the god, the sanctuary of Zeus Ammon at Aphytis presents certain characteristics uncommon in ancient Greek architecture, such as the open-air corridor flanked by the two rows of monumental bases (Fig. 19). The Egyptians wanted their temples to constitute a significant element of the landscape and therefore, open-air courts, corridors with colonnades or rows with bases supporting sphinxes were common features. ${ }^{27}$

The existence of the open-air corridor flanked by two rows of monumental bases, which probably supported sculpture, recalls the temple of the Theban triad at Deir el Haggar, equipped with two rows of six monumental bases. ${ }^{28}$

The temple of Zeus Ammon at Aphytis is on a N-S axis and consists of a pronaos and cella, like the temple under the trees at the oracle of Siwah, as it is described by travelers of the $18^{\text {th }}$ century and the brief investigation that was carried out. ${ }^{29}$

Ammon's sanctuary at Siwah was an oracle, but there is no evidence concerning the way consultations were given. Plutarch mentions that it had an oneiric function. It is also probable that it functioned with ecstatic utterances, or interpretation of the noise of bronze vessels. Another function has also been suggested: on festival days, when the god was carried in procession by his priests, the spirit of the god determined the movements of the priests and consultation was conducted orally. ${ }^{30}$

The sanctuary of Zeus Ammon at Aphytis (Kallithea) must have functioned as an oracle too, with consultations probably given in one of the ways mentioned above.

${ }^{26} \mathrm{COOK}$, o.c. (n. 23), p. 348-353.

27 S. Quirke, The Temples of Ancient Egypt, London, 1993; M. Murray, Egyptian Temples, London, 1946.

${ }^{28}$ MURray, o.c. (n. 27).

29 A. FAKHry, The Oasis of Egypt. I. Siwa Oasis, Cairo, 1995.

30 Plutarch, Lysander, 20, 4 and H.W. PARKe, The Oracles of Zeus, Dodona, Olympia, Ammon, Oxford, 1967, p. 195-200. 


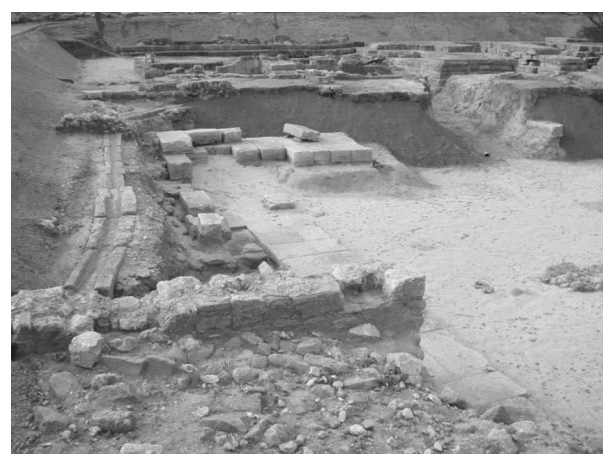

Fig. 18: The water channel that drained the water from the structure in front of the temple.

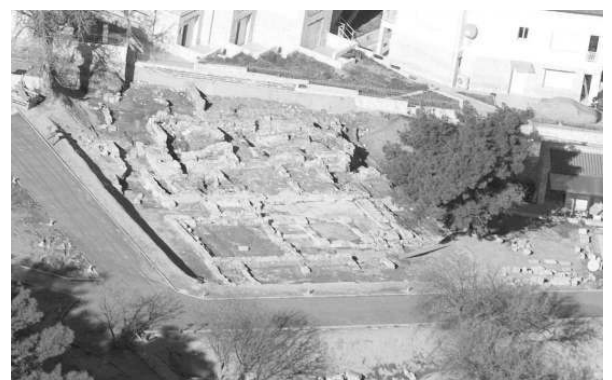

Fig. 20: The Roman balneum

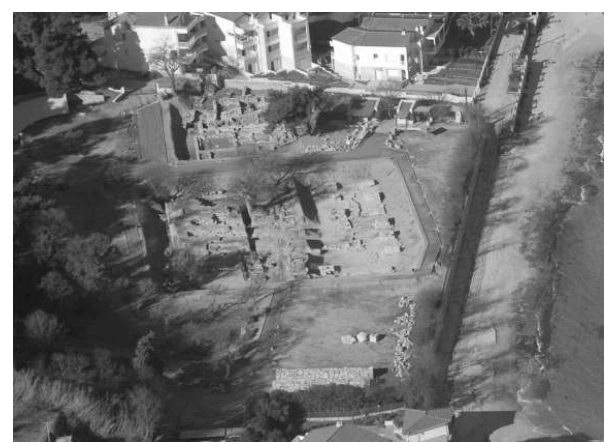

Fig. 19: The temple of Zeus Ammon and the open-air corridor flanked by two rows of monumental bases.

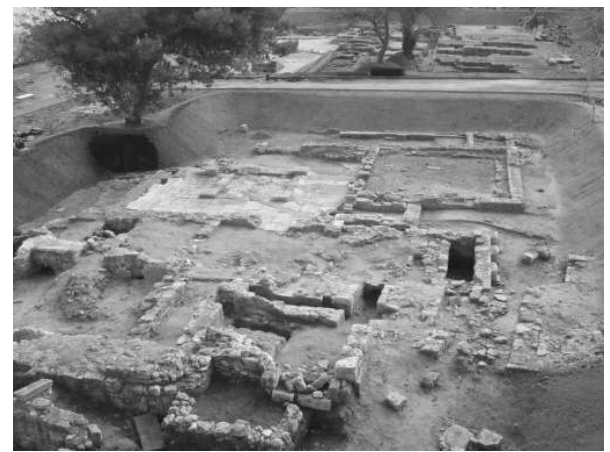

Fig. 21: The frigidarium: the central area, the apodyterium and the pool.

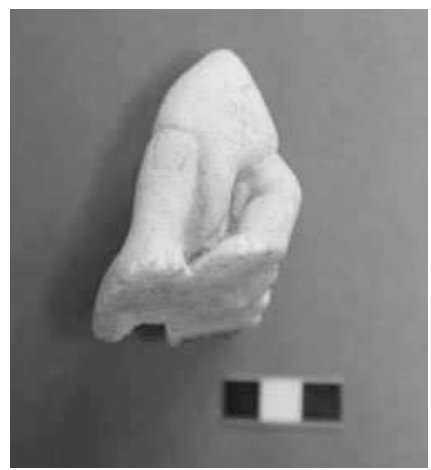

Fig. 24: Hand of Hygeia holding a snake.
Fig. 23: The apodyterium: the northern area of the sanctuary, north of the temple of Zeus Ammon, where Asclepios was worshipped.

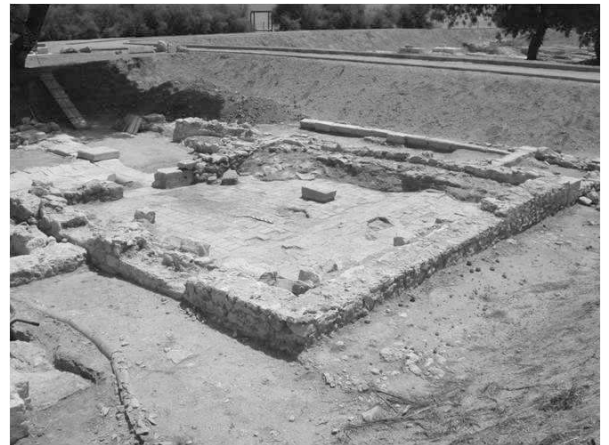




\section{The Roman balneum and the cult of Asclepios}

\subsection{The Roman balneum}

Excavation of the balneum began in 2005. ${ }^{31}$ It belongs to the single-axis row type with all the rooms, frigidarium, tepidarium and caldarium, on the north-south axis (Fig. 20). This type appeared in the Roman Republic and remained the most common in the eastern provinces of the Roman Empire until the Byzantine period. ${ }^{22}$ The entrance of the bath is found to the south and part of it was destroyed by an illegal building trench.

The frigidarium is located immediately after the entrance (Fig. 21). It is oblong with a central square area lined with slabs and four columns at the corners, and was originally equipped with a structure related to water. The walls were covered with frescoes, remains of which were found during the excavation, and the room was also decorated with marble statues, fragments of which were found during the recent investigation. An apodyterium with benches along its three walls is found west of the frigidarium and a pool with cold water is situated to the east (Fig. 22).

The tepidarium is situated next to the frigidarium to the north. Its walls and floor were equipped with systems of heating. ${ }^{33}$ The room was originally equipped with marble basins, parts of which have been discovered in excavation. ${ }^{34}$

The caldarium occupies the northernmost part of the balneum and its northern wall is equipped with a niche which housed a basin in the interior. Its floor and walls were equipped with heating systems and the room had a number of basins. $^{35}$

31 Tsigarida, VASILIEIOU, l.c. (n. 3).

32 I. NiELSEN, Thermae et Balnea. The Architecture and Cultural History of Roman Republic Baths, Aarhus, 1990; I. KRENCKER, R. Ginouvès, Balaneutikè. Recherches sur le bain dans l'antiquité grecque, Paris, 1962, p. 174-187; E.Y YEGúl, Baths and Bathing in Classical Antiquity, New York, 1992,

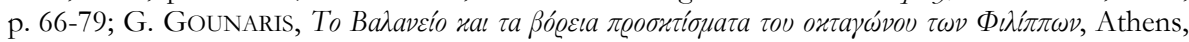
1990, p. 110-203.

33 J.P. ADAM, La construction romaine, matriaux et techniques, Paris, 1989, p. 243, fig. 630; NIELSEN, l.c. (n. 32), p. 155-156. Its walls were equipped with pi-shaped clay oblong plaques instead of the usual tegulae mammatae, which are found in other baths. St. ELEUTHERATOU, "To $\alpha v \alpha \tau o \lambda \iota x o$ '

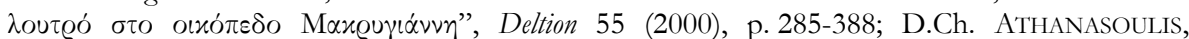

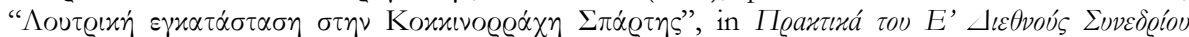

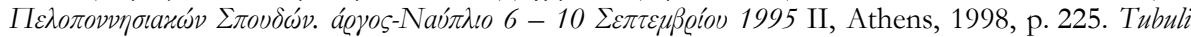
were also used for the heating of the walls, like those recovered at the bath of Marathon, see

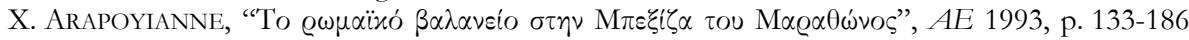
and ADAM, l.c. (n. 33), fig. 633. The floor of the room was equipped with a heating system (hypocaust) consisting of brick arches which supported the floor.

34 The excavation of the tepidarium is not yet complete.

35 The hypocaust consists of pillars of bricks: ADAM, l.c. (n. 33), fig. 634. 
The furnace and boilers are found west of the caldarium. ${ }^{36}$ Originally, they were situated west of the tepidarium, but in a later phase they were moved. An extended layer of ashes, found north-west of the balneum, implies its long use.

The bath was built in the $2^{\text {nd }}$ century $\mathrm{AD}$ during a peak period for the sanctuary, and continued in use until the mid- $4^{\text {th }}$ century. During this long period of two hundred years, two repairs which changed its plan and the use of some rooms, took place. During the first repair, the furnace and the boiler, which were originally west of the tepidarium, were moved to the north, west of the caldarium. Furthermore, the northern part of the apodyterium was separated from the rest and was transformed into a cistern, and the western wall of the apodyterium was moved further west, enlarging the room.

A second repair dates to the end of the $3^{\text {rd }}$ century, probably after the invasion of the Goths, who besieged Cassandreia in 268-9. Benches were constructed along the three walls of the apodyterium and covered the frescoes of the room; furthermore the wall-paintings of the southern wall of the frigidarium were also covered, while the size of the pool was decreased. There were no alterations to the tepidarium and the caldarium, which do not seem to have been in use after the Goth invasion. ${ }^{37}$

The excavation yielded interesting finds including pottery, architectural details, and fragments of marble statues which originally decorated the bath.

\section{The Cult of Asclepios}

A votive inscription in honor of Asclepios dated to the late $3^{\text {rd }}$ or the first half of the $2^{\text {nd }}$ century $\mathrm{BC}$, which had been removed from the sanctuary by the monks and was discovered by Manolis Voutiras in the monastery of Panteleemon on Mt Athos, provides evidence on the worship of the god in the sanctuary. ${ }^{38}$ This is further supported by the information that Cassandreia, the main city in the area, participated in the new Panhellenic Festival in honor of Asclepios which started in 242 BC at Kos. ${ }^{39}$ Although there is not much evidence on the spread of the cult of Asklepios in Macedonia, ${ }^{40}$ it is known that

36 For the furnace (praefurnium) and boilers, see Eleutheratou, l.c. (n. 33); NiELSEN, o.c. (n. 32), p. 162; GOUNARIS, o.c. (n. 32), p. 27; YEGÚ, o.c. (n. 32), p. 310-311.

37 The plan and function of many Roman baths changed when Christianity became the formal

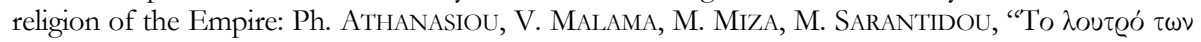

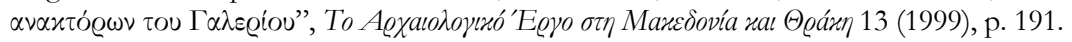

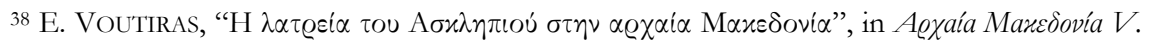

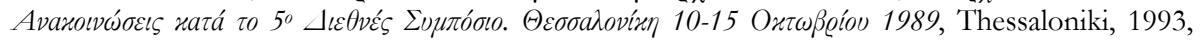
p. 258-259. and 7,1

39 R. Herzog, G. Klaffenbach, Assylieurkunden aus Kos, Abh. Akad. Berlin, 1952, p. 6, 1

40 See Voutiras, l.c. (n. 38), p. 251-265. 
Asclepios had been worshipped in Aphytis from the second quarter of the $4^{\text {th }}$ century BC. ${ }^{4}$

Asclepios is a deity related to water and balnea. Thus, since his worship in the sanctuary was suggested by the honorary inscription, the balneum must have been erected by his shrine. The balneum is situated in the northern part of the sanctuary, north of the temple of Zeus Ammon, where the cult of the god was probably located. During the excavation of a neighbouring building lot, north of the sanctuary, a stoa equipped with rooms with large openings was discovered. Its investigation yielded a large number of cups, plates and amphoras, pots used for drinking and eating. ${ }^{42}$ The stoa faces south and probably constituted the northern boundary of the sanctuary. Next to this stoa, there are two rooms, one of which yielded surgical implements and the other remains of food preparation. The stoa was built in the second half of the $4^{\text {th }}$ century $\mathrm{BC}$ and was destroyed by the end of the century, like the temple of Zeus Ammon, and probably by the same cause, an earthquake. However, the temple was repaired and reused, while the stoa was not. Later, other buildings were erected on top of it. It is well known that festive meals played an important role in the cult of Asclepios..$^{43}$ The plan of the stoa with the rooms with large openings and the finds from its excavation suggest that it was used for banqueting. This is further supported by the neighbouring room with remains of food preparation. The stoa was built in the second half of the $4^{\text {th }}$ century and according to the written sources the cult of Asclepios existed in Aphytis in 360 BC. Thus, it is highly probable that the god was worshipped in this northern part of the sanctuary as early as the second half of the $4^{\text {th }}$ century BC.

Furthermore, the existence of the room with the surgical implements also testifies to a connection with Asclepios. The proximity of the balneum to this room, a marble fragment of a hand holding a snake, which was found in the frigidarium of the balneum and which recalls statues of Hygeia holding a snake, suggests that the balneum was used in the cult of the god, and thus, it can be characterized as a therapeuterion (Fig. 23).

The healing abilities of the sanctuary were mentioned by Xenophon, in his story about the Spartan king Agesipolis, who fell ill during a naval battle at Torone and asked to be taken to the sanctuary of Dionysus to be healed, but who died before he reached it. ${ }^{44}$

${ }^{41}$ IG IV I 2, 94: Aphytis is recorded in the list of the theorodokoi of Epidaurus. The inscription dates to $360 / 59 \mathrm{BC}$.

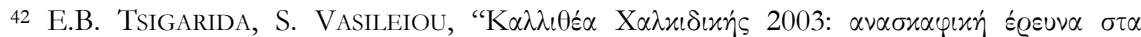

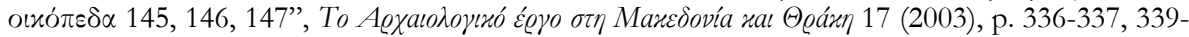
340 .

43 M.H. JAMESON, “Theoxenia”, in R. HÄGG (ed.), Greek Cult Practice from Epigraphical Evidence. Proceedings of the Second International Seminar on Ancient Cult, organized by the Swedish Institute of Athens, 22-24 November 1991, Stockholm, 1994, p. 35-57.

${ }^{44}$ Xen., Hell. V, 3, 19. 


\section{Conclusions}

Concluding, we would like to point out the following: the three deities worshipped at the sanctuary were related. Dionysos was supposed to be the son of Zeus Ammon and was himself a horned god. He was worshipped near the cave, probably together with the nymphs. In the first half of the $4^{\text {th }}$ century the cult of Zeus Ammon was introduced, and in the second half of the century the cult of another related god, Asclepios - the Roman horned god, Sarapis. The sanctuary was related to the city of Cassandreia and became important during the Hellenistic period. It was repaired and reorganized in the $2^{\text {nd }}$ century $\mathrm{AD}$ and was completely abandoned in the $4^{\text {th }}$ century.

Elisavet Bettina TSIGARIDA

$16^{\text {th }}$ Ephorate of Prehistoric and Classical Antiquities

Proektasi Megalou Alexandrou

Opposite Poseidonion

GR - 54646 THESSALONIKI

E-mail:tsigarida@soulakis.gr 